\title{
Detection of Virulence Genes in Bacillus cereus isolated from Meat Products Using PCR
}

\author{
Ashraf A. Abd El Tawab ${ }^{1 *}$, Fatma I. El-Hofy ${ }^{1}$, Nahla, A.Abou El Roos ${ }^{2}$ and Doaa, A.El-morsy ${ }^{2}$ \\ ${ }^{1}$ Bacteriology, Immunology and Mycology Department Faculty of Veterinary Medicine, Banha University, Egypt. \\ ${ }^{2}$ Animal Health research institute, Shibin El Kom Branch, Egypt. \\ *Corresponding author's Email: Ashrafabdeltwab@yahoo.com; ORCID: 0000-0002-1221-3340
}

Received: 21 Feb. 2020

Accepted: 30 Mar. 2020

\begin{abstract}
Bacillus cereus is an opportunistic pathogen that can cause food poisoning in humans as a result of consuming foods containing toxins or bacteria. In this study, the incidence of B. cereus and its virulence genes in meat products was investigated. Isolation of $B$. cereus was performed using selective PEMBA media and confirmed by morphological and biochemical tests and Vitek2 compact system. The incidence of B. cereus strains in beef and chicken meat products was $28 \%$. The incidence of Bacillus cereus in frozen rice kofta, frozen kobiba-shami, chicken pane, and chicken nuggets was $16 \%, 24 \%, 28 \%$, and $44 \%$, respectively. Moreover, the result of multiplex PCR of virulence genes of groEL gene (533bp), Hbl gene (1091 bp), Nhe gene (766 bp) and Cytk gene (421bp) indicated that groEl gene, Nhe gene, Cytck gene was found in $100 \%$ of B. cereus isolated from different meat products, while $\mathrm{Hbl}$ gene was detected in $10 \%$ of isolates. The results demonstrate that meat products represent a threat to public health through the transmission of Bacillus cereus.
\end{abstract}

Key words: Bacillus cereus, Beef meat, Chicken meat, PCR, Virulence genes, VITEK2

\section{INTRODUCTION}

The genus Bacillus includes harmless environmental and pathogenic species. The B. cereus group is known as pathogens or opportunistic pathogens to humans (Logan, 2012). The B. cereus is associated with food poisoning as a result of the consumption of food containing pre-formed toxins or bacteria producing toxins in the human gut (McKillip, 2000).

Genus Bacillus are Gram-positive rods able to produce endospores resistant to unfavorable external conditions (Logan and Devos, 2009) that can be distinguished from other spore-formers (Sporolactobacillus, Clostridium, Desulfotomaculum, Sporosarcina, and Thermoactinomyces) due to their aerobic character (strict or facultative), rod-shaped cells and catalase production (Slepecky and Hemphill, 2006). Schedule identification of $B$. cereus is generally combined with isolation on selective media, illuminating of motility, hemolysis pattern on blood agar, and acidification of glucose (Stenfors et al., 2008).

The pathogenesis of $B$. cereus-induced food poisoning is mostly still unclear. The microorganism transmits an expansive number of potentially toxic components, including hemolysins, phospholipases, and proteases (Beecher, 2001) nevertheless, the accurate role of some toxins is still unclear. The emetic and the diarrheal syndromes are still the foremost concerns for the public health apprehension and the full appreciative of their pathogenesis is imperative. These syndromes are mainly revealed via the release of two core toxins, a heatlabile diarrheal enterotoxin, and heat-stable emetic enterotoxin (Stenfors et al., 2008).

The diarrheal syndrome revealed via the release of one or three diarrheal enterotoxins: the tripartite toxins hemolysin BL $(H B L)$ and non-hemolytic enterotoxin (Nhe), the two forms of cytotoxin $\mathrm{K}$ (cytK-1 and cytK-2) and possibly enterotoxin $\mathrm{T}$ and enterotoxin $\mathrm{FM}$ (Moravek et al., 2006). HBL is a three-component toxin, that is encoded by $h b l D$ and $h b l C$ genes respectively, and a binding component $\mathrm{B}$ encoded by hblA gene. The presence of all three components is important for the activity of toxin (Lindback and Granum, 2006).

The objective of this study was to conduct bacteriological and molecular studies on B. cereus isolated from frozen rice kofta, frozen kobiba-shami, chicken pane, and chicken nuggets. 


\section{MATERIALS AND METHODS}

\section{Collection of Samples}

A total of one hundred random samples of meat products which including frozen rice kofta, frozen kobibashami, chicken pane and chicken nuggets (25 of each) were collected from different shops, supermarkets in different localities in Menoufia and Kalyobia governorates. Samples conveyed to the laboratory following aseptic and safety precautions.

\section{Isolation and identification of Bacillus cereus} group

A stomacher was used to homogenize $10 \mathrm{~g}$ of each sample in $90 \mathrm{~mL}$ of buffered peptone water (BPW) for $2 \mathrm{~min}$. Heat treatment of all samples at $70{ }^{\circ} \mathrm{C}$ for $15 \mathrm{~min}$ was used to eliminate vegetative cells and allow the isolation of spores (Al- Allaf, 2011). The pasteurized samples were immediately positioned in ice to prevent spore germination. An amount of $100 \mu \mathrm{l}$ was spread on Polymyxin-pyruvate-Egg yolk-Mannitol-Bromothymol blue agar (PEMBA) media plates and incubated at $37{ }^{\circ} \mathrm{C}$ for 24-hr both aerobically and anaerobically. The plates were examined and the presumptive B. cereus group was confirmed based on microscopy of Gram-stained preparations and biochemical tests (FDA, 2015). A number of colonies were randomly collected and analyzed by cell morphology under the microscope, Gram staining, ability to form endospores, growth in the presence of sodium chloride, anaerobic growth, catalase and oxidase activity, Voges-Proskauer test and growth at $\mathrm{pH}$ 5.7. The ability to ferment carbohydrates, starch hydrolysis, use of citrate as a carbon source, lecithinase activity, and growth inhibition by lysozyme were applied (Al- Allaf, 2011 and FDA, 2015).

\section{Identification of Bacillus cereus using VITEK2} BCL Card

Bacterial suspensions were arranged in $3.0 \mathrm{~mL}$ of sterile saline and accustomed to a McFarland standard of 1.80-2.20 using the VITEK2 DensiChek (bioMe'rieux). BCL cards were packed automatically in the VITEK vacuum chamber, sealed, incubated at $35.5^{\circ} \mathrm{c}$ and read automatically every $15 \mathrm{~min}$ for 14 hours. Data were investigated automatically using the VITEK2 database.

\section{PCR detection of virulence Bacillus cereus isolates} DNA extraction

The isolates of $B$. cereus isolates from different meat products were grown in $5 \mathrm{~mL}$ nutrient broth with shaking for $18 \mathrm{~h}$ at $30^{\circ} \mathrm{C}$ and collected at $5,000 \mathrm{~g}$ for $5 \mathrm{~min}$. QIAamp DNA Mini Kit was used for genomic DNA extraction and purification. PCR was achieved to detect groEl gene and three enterotoxigenic encoding endotoxins genes Nhe, hbl and cytK genes. A positive reference strain of $B$. cereus ATCC 14579 and sterile MilliQ water as a negative control was used in PCR analysis (Ehling-Schulz et al., 2006; Das et al., 2013). Table 1 provides details about the primers used.

\section{Preparation of PCR master mix}

occurred according to Emerald Amp GT PCR mastermi (Takara) CodeNo.RR310A kit as shown in table 2.

\section{Cycling conditions of the primers during PCR}

PCR conditions are shown in table 3. Gel electrophoresis was used to analyze PCR fragments for presence and correct size compared to positive control (Sambrook et al., 1989). PCR runs where a negative control displayed amplification or positive control did not amplify were overlooked and repeated.

\section{RESULTS}

\section{Prevalence of Bacillus cereus in meat products}

The prevalence of $B$. cereus in meat products (frozen rice kofta, frozen kobiba-shami, chicken pane, and chicken nuggets) was $16 \%, 24 \%, 44 \%$, and $28 \%$, respectively. Out of 28 Bacillus isolates, 18 (36\%) isolates obtained from chicken product samples and $10(20 \%)$ isolates were recovered from beef product samples. The incidence of $B$. cereus group in the different meat products shown in table 4.

\section{PCR results}

The result obtained using agarose gel electrophoresis of multiplex PCR of virulence genes, groEL gene (533bp), $\mathrm{Hbl}$ gene (1091 bp), Nhe (766 bp) and Cytk gene (421bp) for characterization of virulence genes of $B$. cereus isolated from different meat products showed that groEL gene (Figure 1), Nhe gene (Figure 3) and Cytk gene (Figure 4) were found in $100 \%$ of tested isolates of $B$. cereus and the $\mathrm{Hbl}$ gene was detected in $10 \%$ of tested $B$. cereus isolates (Figure 4). 
Table 1. Oligonucleotide primers sequences used in this study to detect Bacillus cereus

\begin{tabular}{|c|c|c|c|}
\hline Gene & Primer sequence & $\begin{array}{l}\text { Length of amplified } \\
\text { product (base pair) }\end{array}$ & Reference \\
\hline \multirow{2}{*}{ groEL } & F: 5'- TGCAACTGTATTAGCACAAGC T -3' & \multirow{2}{*}{533} & \multirow{2}{*}{ Das et al. (2013) } \\
\hline & R: 5'-TACCACGAAGTTTGTTCACTACT-3' & & \\
\hline \multirow{2}{*}{ Nhe } & F: 5'-AAG CIG CTC TTC GIA TTC-3' & \multirow{2}{*}{766} & \multirow{2}{*}{ Ehling-Schulz et al. (2006) } \\
\hline & R: 5'-ITI GTT GAA ATA AGC TGT GG-3' & & \\
\hline \multirow{2}{*}{$\operatorname{cyt} K$} & F: 5'-ACA GAT ATC GGI CAA AAT GC-3' & \multirow{2}{*}{421} & \multirow{2}{*}{ Ehling-Schulz et al. (2006) } \\
\hline & R: 5'-CAA GTI ACT TGA CCI GTT GC-3' & & \\
\hline \multirow{2}{*}{$\mathrm{Hbl}$} & F: 5'-GTA AAT TAI GAT GAI CAA TTTC-3' & \multirow{2}{*}{1091} & \multirow{2}{*}{ Ehling-Schulz et al. (2006) } \\
\hline & R: 5'-AGA ATA GGC ATT CAT AGA TT-3' & & \\
\hline
\end{tabular}

Table 2. PCR master mix component used for PCR reaction for detection of virulence genes of Bacillus cereus

\begin{tabular}{lc}
\hline Component & Volume \\
\hline Emerald Amp GT PCR mastermix (2x premix) & $12.5 \mu 1$ \\
PCR grade water & $4.5 \mu l$ \\
Forward primer(20 pmol) & $1 \mu 1$ \\
Reverse primer (20 pmol) & $1 \mu 1$ \\
Template DNA & $6 \mu 1$ \\
Total & $25 \mu 1$ \\
\hline
\end{tabular}

Table 3. Temperature and time conditions used during PCR assay

\begin{tabular}{|c|c|c|c|c|c|c|}
\hline Gene & $\begin{array}{c}\text { Primary } \\
\text { denaturation }\end{array}$ & $\begin{array}{c}\text { Secondary } \\
\text { denaturation }\end{array}$ & Annealing & Extension & No. of cycles & $\begin{array}{c}\text { Final } \\
\text { extension }\end{array}$ \\
\hline groEL & $\begin{array}{l}94^{\circ} \mathrm{C} \\
5 \mathrm{~min} .\end{array}$ & $\begin{array}{c}94^{\circ} \mathrm{C} \\
30 \mathrm{sec} .\end{array}$ & $\begin{array}{c}55^{\circ} \mathrm{C} \\
40 \mathrm{sec} .\end{array}$ & $\begin{array}{c}72^{\circ} \mathrm{C} \\
45 \mathrm{sec} .\end{array}$ & 35 & $\begin{array}{c}72^{\circ} \mathrm{C} \\
10 \mathrm{~min} .\end{array}$ \\
\hline Nhe, hbl, cytK & $\begin{array}{l}94^{\circ} \mathrm{C} \\
5 \mathrm{~min} .\end{array}$ & $\begin{array}{c}94^{\circ} \mathrm{C} \\
30 \mathrm{sec} .\end{array}$ & $\begin{array}{c}49^{\circ} \mathrm{C} \\
40 \mathrm{sec} .\end{array}$ & $\begin{array}{l}72^{\circ} \mathrm{C} \\
1 \mathrm{~min} .\end{array}$ & 35 & $\begin{array}{c}72^{\circ} \mathrm{C} \\
10 \mathrm{~min} .\end{array}$ \\
\hline
\end{tabular}

Table 4. Incidence of Bacillus cereus isolated from examined meat products

\begin{tabular}{|c|c|c|c|c|c|c|}
\hline Products & $\begin{array}{c}\text { Kobiba- } \\
\text { shami }(n=25)\end{array}$ & $\begin{array}{c}\text { Rice kofta } \\
(\mathbf{n}=25)\end{array}$ & $\begin{array}{c}\text { Total beef } \\
\text { products } \\
(\mathbf{n = 5 0 )}\end{array}$ & $\begin{array}{c}\text { Chicken } \\
\text { pane }(n=25)\end{array}$ & $\begin{array}{c}\text { Chicken } \\
\text { nuggets }(n=25)\end{array}$ & $\begin{array}{c}\text { Total chicken } \\
\text { products } \\
(\mathbf{n}=\mathbf{5 0})\end{array}$ \\
\hline Percentage of positive samples & $24 \%$ & $16 \%$ & $20 \%$ & $44 \%$ & $28 \%$ & $36 \%$ \\
\hline
\end{tabular}




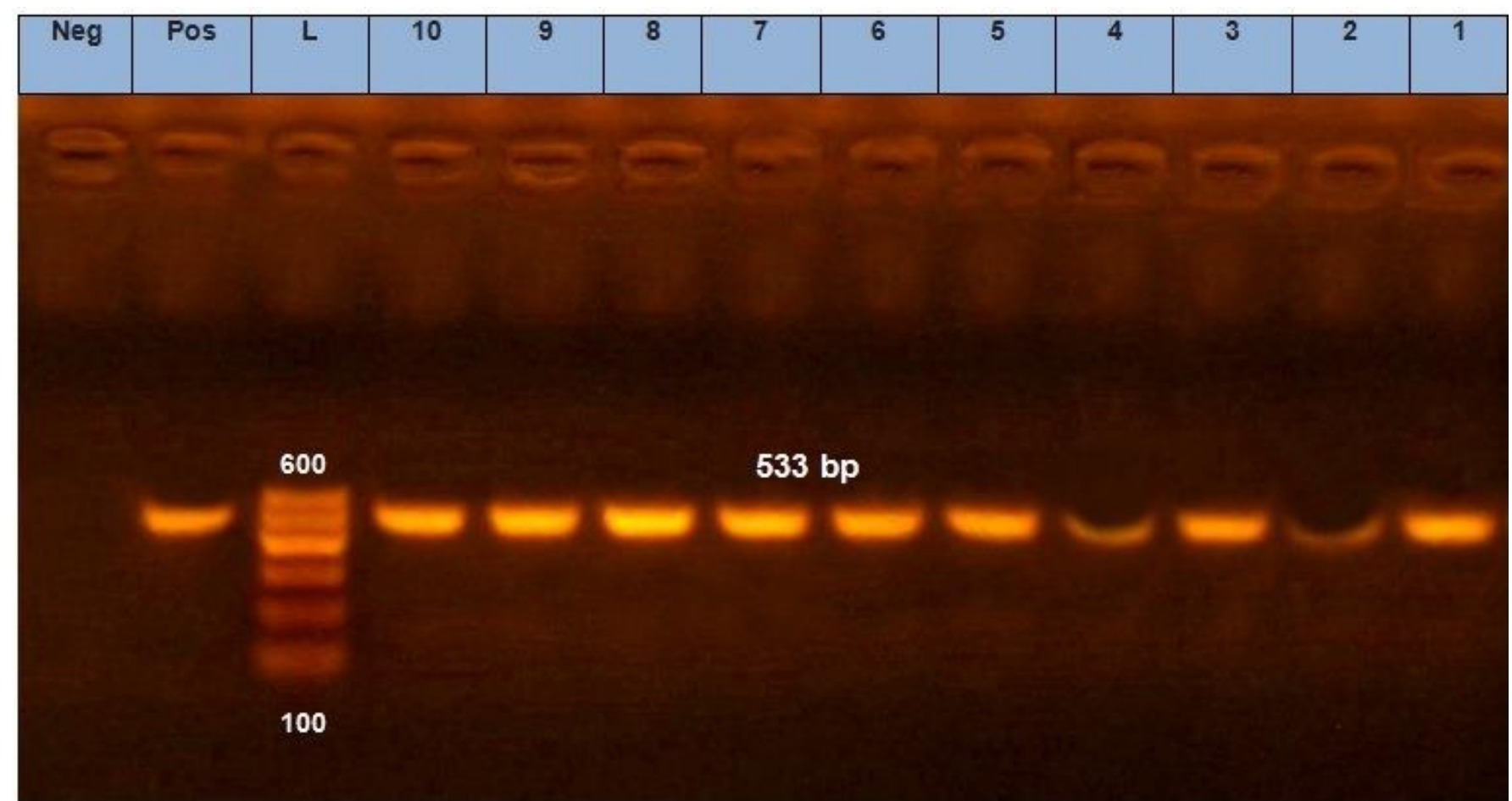

Figure 1. Results of PCR amplification of groEl gene of Bacillus cereus isolated from different meat and chicken products. Neg: negative control, Pos: positive control, Lane L: 100-600 bp DNA ladder, Lane 1-10: positive samples at 533 bp

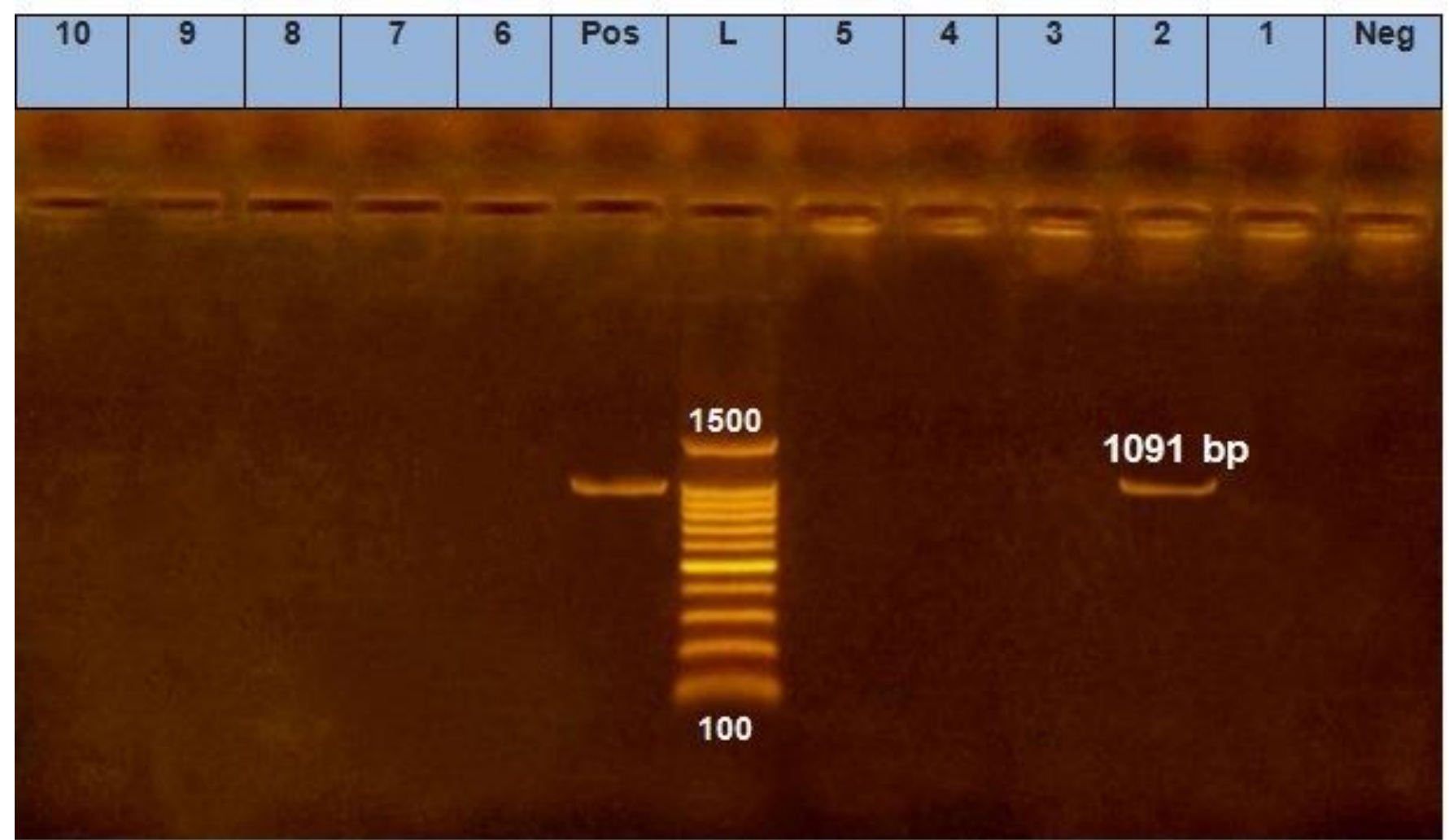

Figure 2. Results of PCR amplification of $h b l$ gene of Bacillus cereus isolated from different meat and chicken products. Neg: negative control, Pos: positive control, Lane L: 100-1500bp DNA ladder, Lane 2: positive sample at 1091 bp. Lane 1, 3, 4, 5, 6, 7, 8, 9, and 10: negative samples. 


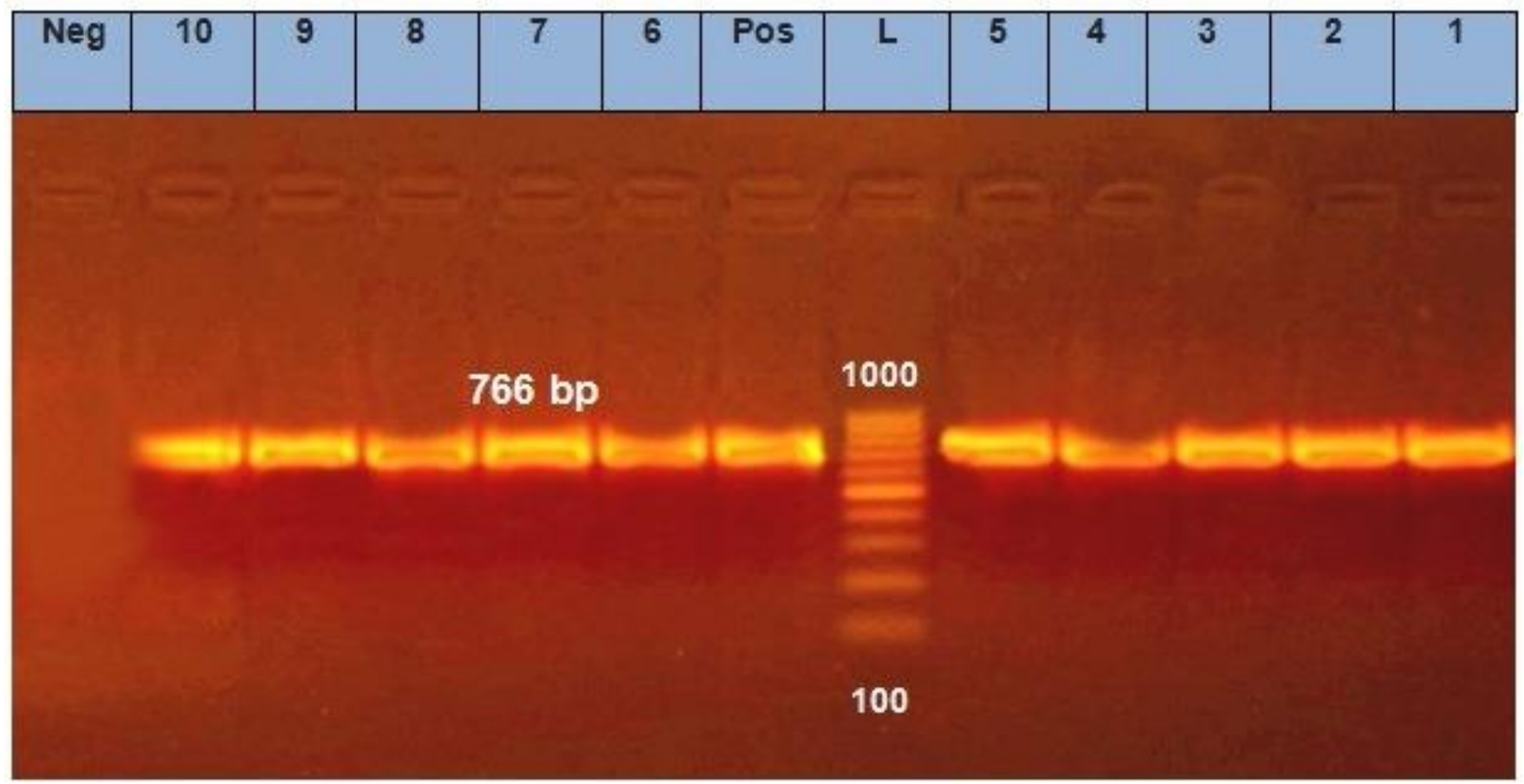

Figure 3. Results of PCR amplification of Nhe gene of Bacillus cereus isolated from different meat and chicken products. Neg: negative control, Pos: positive control, Lane L: 100-1000bp DNA ladder, Lane 1-10: positive samples at 766 bp.

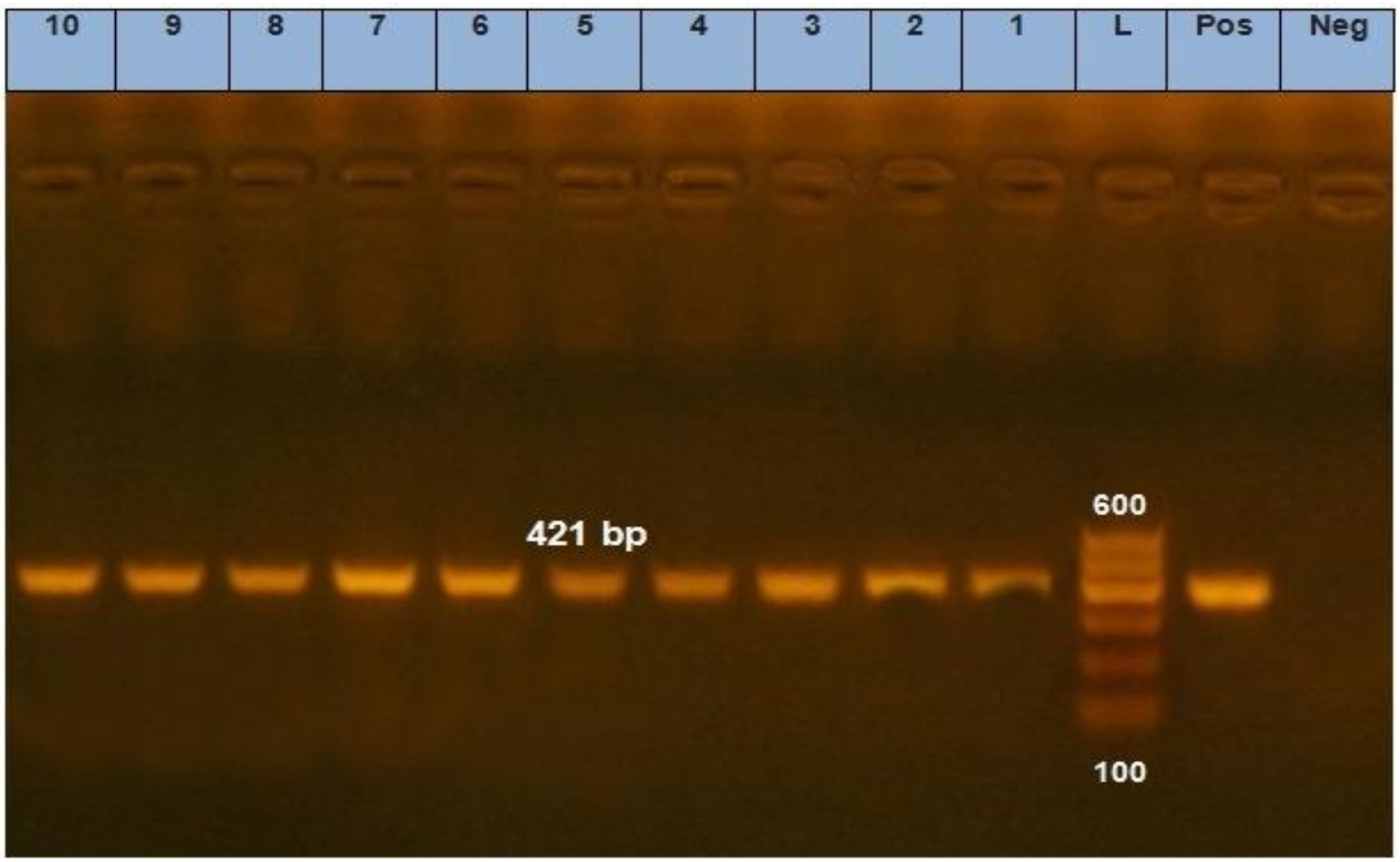

Figure 4. Results of PCR for amplification of cytK gene of Bacillus cereus isolated from different meat and chicken products. Neg: negative control, Pos: positive control, Lane L: 100-600bp DNA ladder, Lane 1-10: positive samples at 421 bp. 


\section{DISCUSSION}

Food-borne diseases are reported to be a serious hazard to public health all over the world. Among the organisms responsible for causing foodborne diseases, B. cereus has emerged as a major foodborne pathogen during the last few decades and causes two types of illness through the elaboration of enterotoxins (Jay, 2005).

In this study, the incidence of $B$. cereus in meat products was $28 \%$. These results were nearly similar to that obtained by Tewari et al. (2015), who isolated $B$. cereus from $35 \%$ of meat products. The results of the present study were higher than those obtained by Ashraf et al. (2019), who isolated B. cereus at a percentage of 11.24 , while the results were lower than those obtained by Shimaa et al. (2018) who isolated B. cereus at a percentage of $47 \%$.

The incidence of $B$. cereus in beef meat products was $20 \%$ that was lower than that obtained by Hesham et al. (2018), where the incidence of B. cereus was $38.2 \%$. The incidence of $B$. cereus in chicken meat products was $36 \%$ nearly similar to results obtained by Hesham et al. (2018), who isolated B. cereus from chicken meat products at a rate of $48 \%$.

The incidence of $B$. cereus in Kobeba-shami was $24 \%$. This result was lower than that obtained by Shimaa et al. (2018) where the incidence of B. cereus was $52 \%$ and Hemmat et al. (2014) who isolated B. cereus from $84 \%$ of the examined kobeba-shami samples. The incidence of B. cereus in Rice kofta was $16 \%$. This result was lower than that obtained by Shimaa et al. (2018) who isolated B. cereus at a rate of $60 \%$. The incidence of $B$. cereus in nuggets was $28 \%$. This result was lower than that obtained by Smith et al. (2004) who isolated B. cereus at a percentage of $91.6 \%$. The incidence of $B$. cereus in chicken pane was $44 \%$ that was higher than that obtained by Smith et al. (2004) who failed to isolate B. cereus from examined chicken products.

These variations in the results were attributed to the quality of raw materials and the hygienic state during the preparation and processing of the product. The high frequency of isolation of $B$. cereus from meat products may be attributed to the processing of minced meat also additives and spices added to these products, which can increase the number of Bacillus spores. Therefore it is important to use additives from a trustful source during the processing of raw meat and test these additives regularly for the presence of Bacillus spore (Shawish and Tarabees,
2017). VITEK2 BCL Card is a highly advanced method for the identification of B. cereus (Halket et al., 2010).

In this study, $100 \%$ of tested B. cereus isolates harbored Nhe gene that this result is in accordance with that presented by Anderson et al. (2001) and Ashraf et al. (2019), while $\mathrm{Hbl}$ gene was found in $10 \%$ of the tested isolates, which is similar to findings reported by Ashraf et al. (2019). Also, $100 \%$ of tested B. cereus were found to harbor $c y t k$ gene and this result approved with Kamelia et al. (2018) (81.5\%) and Ngamwongsatit et al. (2008). Also, groEl gene was present in $100 \%$ of tested B. cereus which is a valuable target for phylogenetic studies to detect the $B$. cereus (Chang et al., 2003) and has already been used in PCR assay to detect the B. cereus (Taylor et al., 2005; Chang et al., 2003).

\section{DECLARATIONS}

\section{Acknowledgments}

This study was supported by Animal Health Research Institute (AHRI) in Doki and AHRI in Shibin El Kom branch.

\section{Competing interests}

No competing interest exists

\section{Authors' contributions}

All authors contributed equally to this work.

\section{REFERENCES}

Al-Allaf MAA (2011). Isolation of Bacillus spp. from some sources and study of its proteolytic activity. Tikrit Journal of Pure Science, 16 (4): 59-63. Available at https://www.iasj.net/iasj?func $=$ article \&aId=37552

Anderson BGI, Skeie M, Sorhaug T, Langsrud T and Granum PE (2001).Growth and toxin profiles of Bacillus cereus isolated from different food sources. International Journal of Food Microbiology, 69 (3):237-246. DOI: https://doi.org/10.1016/S01681605(01)00500-1

Ashraf A Abd El Tawab, Fatma I El-Hofy, Khalid I El-Ekhnawy and Heba E El-Shora (2019). Detection of some virulence and resistance genes of $S$. aureus and B. cereus isolated from some meat products. Nature and Science, 17(2): 85-91. DOI: http://www.dx.doi.org/10.7537/marsnsj170219.09

Beecher DJ (2001). The Bacillus cereus group. In: Turnbull PCB (editor). Gastro-intestinal infections: toxin-associated diseases. London: Academic Press; pp. 1161-1190. Available at https://www.ncbi.nlm.nih.gov/pmc/articles/PMC1951018/

Chang YH, Shangkuan YH, Lin HC and Liu HW (2003). PCR assay of the groEL gene for detection and differentiation of Bacillus cereus group cells. Applied and Environmental Microbiology, 69(8):45024510. Available at: https://www.ncbi.nlm.nih.gov/pubmed/12902235

Das S, Lalitha KV and Thampuran N (2013). Isolation and molecular characterization of atypical enterotoxigenic Bacillus cereus with negative Voges-Proskauer reaction from Indian white shrimp Fenner open aeusindicus (H. Milne Edwards, 1837). Indian Journal 
Abd El Tawab et al., 2020

of Fish, 60(4): 113-117. Available at: https://www.semanticscholar.org/paper/Isolation-and-molecular-characterisation-ofcereus-Das-Lalitha/4361e7895061dccfd960c1f185679204b56dc22a.

Ehling-Schulz M, Guinebretiere M, Monthán A, Berge O, Fricker M and Svensson B (2006). Toxin gene procling of enterotoxic and emetic Bacillus cereus. FEMS Microbiology Letters, 260, 232-240. Available at: https://www.ncbi.nlm.nih.gov/pubmed/16842349

FDA (2015). Bacteriological Analytical Manual Chapter 14 Bacillus cereus U.S. Food and Drug Administration 10903 New Hampshire Avenue Silver Spring, MD 20993 1-888-INFO-FDA (1888-463-6332), Page Last Updated: 08/06/2015.

Halket G, Dinsdale AE and Logan NA (2010). Evaluation of the VITEK2 BCL card for identification of Bacillus species and other aerobic endospore formers. Letters in Applied Microbiology, 50(1):120126. DOI: https://doi.org/10.1111/j.1472-765X.2009.02765.x

Hemmat MI, Amani MS, Dalia AS and Ghada AA (2014). Demonstration of aerobic spore formers in some meat products. Benha Veterinary Medical Journal, 26 (2):219-226. Available at: http:/www.bvmj.bu.edu.eg.

Hesham T, Mohamed M, Aboubaker M, Salah M, Hanan L, Fatim T, Said K, Ashraf A, Ilaria Barbieri and Ibrahim M (2018). Bacillus cereus as an emerging public health concern in Libya: Isolation and antibiogram from food of animal. Libyan Journal of Medical Sciences, 2(2):56-61. Available at: http://www.ljmsonline.com/article.asp?issn=25889044; year=2018;v olume $=2 ;$ issue $=2 ;$ spage $=56 ;$ epage $=61 ;$ aulast $=$ Naas .

Jay JM (2005). Modern Food Microbiology. $4^{\text {th }}$ Edition. CBS Publishers and Distributers Pvt. Ltd. pp.501-503.

Kamelia M, Anthony D, Ahmed Orabi, Khalid S, Ayman S, Turki M, Hassan A, Ihab MI, Ashgan M, Hend MY and Krassimira R (2018). Poultry and beef meat as potential seedbeds for antimicrobial resistant enterotoxigenic Bacillus species: a materializing epidemiological and potential severe health hazard. Scientific Report, 8: $11600 . \quad$ DOI: https://doi.org/10.1038/s41598-01829932-3

Lindback $\mathrm{T}$ and Granum PE (2006). Detection and Purification of Bacillus cereus Enterotoxins. In: Adley CC (editor). Food-Borne Pathogens: Methods and Protocols. Totawa Humana Press, pp. 1524 Available at: https://experiments.springernature.com/articles/10.1385/1-59259-990-7:015

Logan NA (2012). Bacillus and relatives in foodborne illness. Journal of Applied Microbiology, 112:417-429. Available at https://www.ncbi.nlm.nih.gov/pubmed/22121830

Logan NA and DeVos P (2009) .Genus I. Bacillus Cohn 1872, 174AL. In: De Vos P, Garrity G M, Jones D, Krieg N R, Ludwig W, Rainey FA, Schleifer KH and Whitman WB Eds., Bergey's Manual of Systematic Bacteriology, 2nd Edition, Springer, New York, 3, 21128. Available www.scirp.org/(S(i43dyn45teexjx455qlt3d2q))/reference/Reference sPapers.aspx ?ReferenceID $=61678$
McKillip JL (2000). Prevalence and expression of enterotoxins in Bacillus cereus and other Bacillus spp., a literature review. Antonie Van Leeuwenhoek. 77:393-399. DOI: https://doi.org/10.1023/A:1002706906154.

Moravek M, Dietrich R, Buerk C, Broussolle V, Guinebretiere M H, Granum P E, Nguyen C and Märtlbauer E (2006): Determination of the toxic potential of Bacillus cereus isolates by quantitative enterotoxin analyses. FEMS Microbiology Letters, 257 (2): 293 $298 . \quad$ Available https://www.ncbi.nlm.nih.gov/pubmed/16553866

Ngamwongsatit P, Buasri W, Pianariyanon P, Pulsrikarn C, Ohba M, Assavanig A and Panbangred W (2008). Broad distribution of enterotoxin genes (hblCDA, nheABC, cytK, and entFM) among Bacillus thuringiensis and Bacillus cereus as shown by novel primers. International Journal of Food Microbiology, 121 (3):352356. DOI: https://doi.org/10.1016/j.ijfoodmicro.2007.11.013.

Sambrook J, Fritschi EF and Maniatis T (1989). Molecular cloning a laboratory manual, Cold Spring Harbor Laboratory Press, New York. Available https://www.cabdirect.org/cabdirect/abstract/19901616061

Shawish R and Tarabees R (2017): Prevalence and antimicrobial resistance of Bacillus cereus isolated from beef products in Egypt. Open Veterinary Journal, 7(4): 337-341. Available at: https://www.ncbi.nlm.nih.gov/pubmed/29296593

Shimaa Abd El-Wahaab, S M Saad, M A Hassan and Maarouf A (2018). Occurrence of Bacillus Cereus and its virulence genes in some meat products by Multiplex PCR. Benha Veterinary Medical Journal, 34 (3): 158-166. Available at: https://bvmj.journals.ekb.eg/article_44351.html

Slepecky RA and Hemphill HE (2006). The genus Bacillus nonmedical. In: Dworkin M., Falkow S., RosenbergE., Schleifer K. (eds): The Prokaryotes. A Handbook of the Biology of Bacteria. Springer Science + Business Media, New York: 530-555.

Smith DP, Berrang ME, Feldner PW, Phillips RW and Meinersmann RJ (2004). Detection of Bacillus cereus on selected retail chicken products. Journal of Food Protection, 67(8):1770-1773. Available at: https://www.ncbi.nlm.nih.gov/pubmed/15330548

Stenfors-Arnesen LP, Fagerlund A, and Granum PE (2008). From soil to gut: Bacillus cereus and its food poisoning toxins. FEMS Microbiology Reviews, 32:579-606. Available at: https://www.ncbi.nlm.nih.gov/pubmed/18422617.

Taylor JMW, Sutherland AD, Aidoo KE and Logan NA (2005). Heatstable toxin production by strains of Bacillus cereus, Bacillus firmus, Bacillus megaterium, Bacillus simplex and Bacillus licheniformis. FEMS Microbiology Letters, 242(2):313-317. Available at: https://www.ncbi.nlm.nih.gov/pubmed/15621453.

Tewari A, Singh SP and Singh R (2015). Incidence and enterotoxigenic profile of Bacillus cereus meat and meat products of Uttarakhand, India. Journal of Food Science and Technology, 52(3):1796-1801. DOI: https://DOI.org/10.1007/s13197-013-1162-0. 